\title{
Cultural Park with the Concept of Combining the Betawi and Chinese Culture in Taman Sari, West Jakarta, Indonesia
}

\author{
Syarifa Andari ${ }^{1}$ Rudy Trisno ${ }^{1 *}$ \\ ${ }^{1}$ Department of Architecture, Tarumanagara University, S. Parman No. 1, West Jakarta 11440, Indonesia \\ *Corresponding author; rudyt@ft.untar.ac.id
}

\begin{abstract}
Jakarta has many cases regarding intolerance, since it has varieties of ethnic groups and tribes. This worries citizens about the city in the future. However, cases of intolerance can be minimized by giving education to local citizens, since one of its factors is lack of education. Therefore, this project has a purpose to minimize cases of intolerance, by providing a cultural park that hybrids two cultures, the Betawi and Chinese culture. This cultural park can be used as a third-place by local citizens. The third place is an anchor to the first place (home) and second place (workplace). This cultural park is flexible, it can be used as a place to relax or to have informal meetings. As for the methods; Site project analysis; Determining building program; Symbiosis method application; Form follows function method application; Luo shu method application; Final project result. In conclusion, the Mangga Besar Cultural Park is a third place in west Jakarta. It has a purpose to provide education to local citizens about the Betawi and the Chinese culture. The culture park uses the symbiosis method, the form follows the function method and the luo shu concept.
\end{abstract}

Keywords: Cultural Park, Intolerance, Jakarta, Third Place

\section{INTRODUCTION}

Jakarta has varieties of ethnic groups and tribes, one of which are the Betawi tribe. Betawi is the ancestral tribe of Jakarta, and it has many influences from other cultures, such as Chinese culture. Because of its influences, Betawi and Chinese culture has many similarities. Unfortunately, nowadays cases about intolerance that involves some ethnicities in Jakarta are heard, Betawi and Chinese ethnic groups are one of them. Differences trigger social intolerance and social intolerances are triggered by some factors, including lack of education and society. Indonesia is dominated by low-class citizens, who are lacking aspects such as education and economic needs [1]. According to Hunsberger, intolerance is a negative act, that is triggered by 'overgeneralized believes' [2], meaning that for now, the government is currently preparing for the Pancasila ideology consolidation work unit to reinforce diversity [3]. Providing education is a considerable choice to minimize intolerance cases, since lack of education is one of the aspects that made intolerance occur. Delivering education in a more relaxing manner will make learning much more amusing. Thus, the goal of this project is to create an educational place that covers the topic of Betawi and Chinese culture in Mangga Besar, that delivers cultural education in a more relaxing manner. The project will be classified as a third-place category. The benefit of this project is to provide education about both cultures to local citizens.

\section{MATERIAL AND METHOD}

\subsection{Third Place}

Oldenburg [4] stated that the third-place can be interpreted as the following:

1. Neutral Ground: A place that is not bounded by financial and political views, and can be freely accessed.

2. Leveler (a leveling place): A place that does not view its visitor's social status.

3. Where conversation is the main activity: The main reason is to make people socialize.

4. Accessibility and accommodation: Accessible and accommodate surrounding needs.

5. The regulars: A place that can adjust its surroundings.

6. A low profile: A place where it does not differentiate visitors.

7. The mood is playful: Provides a place to relax with no pressure.

8. A home away from home: Provides a comfortable environment like home [4].

Considering on the interpretation of third place, this category suits the goal of the project, which is to create an educational place that delivers education in a more relaxing manner. 


\subsection{Design Concept}

This project has design concepts as the following:

\section{- Symbiosis}

The symbiosis concept in architecture is discovered by Kisho Kurokawa and it has a purpose to combine contradictive concepts [5]. Hence, the exterior and interior concept is a combination of Betawi and Chinese culture.

- Form Follows Function

Established by Louis Sullivan, this concept has a meaning that the form of the building has to follow the function of the building, to create an architecture creation. [6]. The form of the building will follow the functions that are placed following the luo shu concept.

\section{- Luo Shu}

This concept is pictured as a composition of nine squares. Each square has numbers that symbolize phases and are placed following the wind direction [7]:

1. The water phase symbolizes serenity and calmness.

2. The fire phase peaks the spirit of the user. The metal phase symbolizes a dense form of energy.

3 . The wooden phase symbolizes growth and energy expansion.

4. The earth phase moves cyclically and horizontally in an axis [8].

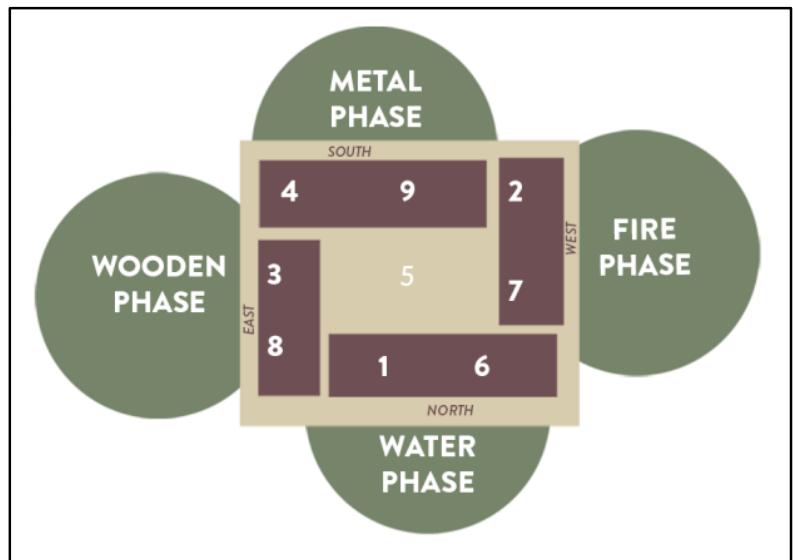

Figure 1. Luo Shu Chart

Source: Author, 2020

\subsection{Design Method}

This project uses methods such as the following:

1. Site Project Analysis

Project site selection took considerations on programs around the site, to match the third-place concept.

2. Determining Building Program

In order to deliver education in a relaxing manner, programs are considered to be amusing.

3. Symbiosis Method Application

Undestranding aspects on both cultures and attempting on combining both cultures.

\section{Luo Shu Method Application}

Understanding the luo shu method and creating zoning based on the luo shu method.

\section{Form Follows Function Method Application}

Creating building mass following the zoning that has been created by following the luo shu method.

6. Final project result

\section{RESULT AND DISCUSSION}

\subsection{Site Project Analysis}

The site is located in Mangga Besar V street, Taman Sari, West Jakarta. It is surrounded by historical recreational places, as shown on figure 2 . This may be an opportunity for the cultural park to be a part of the historical recreational site. The site is accessible from Olimo Transjakarta Bus Stop and Mangga Besar Train Station. The site is located in the mixed zone area, marked as the color yellow. It is surrounded by houses, hotels, stores, offices, and schools as shown on figure 3 . The site is also surrounded by food stalls that are placed at the side of the road, which often causes traffics, espescially at hours when people are going to work and evenings where people are going home from work. Considering on the fengshui aspect, the site does not have any high voltage area nearby, which is good for the energies of people nearby, since high voltage is not good for health [9].

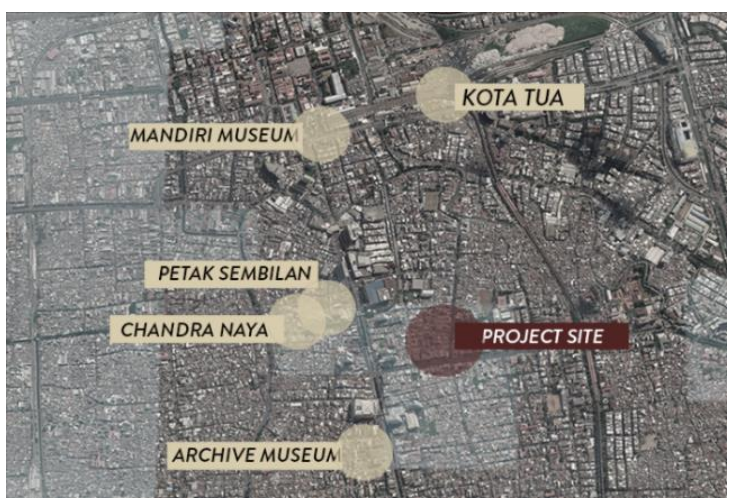

Figure 2. Recreational Site Area;

Source: Author, 2020

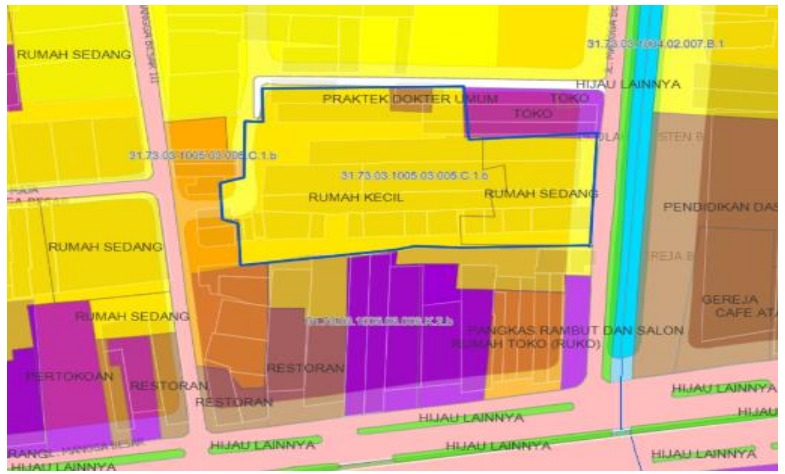

Figure 3. Site Zoning

Source: Jakarta Satu [10] 


\subsection{Determining Building Program}

Mangga Besar Cultural Park has programs as the following:

1. Open Space: This includes courtyards and roof gardens. In these spaces, communication is the main activity.

2. Cultural Workshop: Provides cultural dance and art courses.

3. Culinary: Provides spaces for food stalls on the side of the road.

4. Multifunction Hall Provides spaces for cultural events, bazaars, and others.

5. Cultural Gallery: Provides spaces for temporary art exhibitions.

\subsection{Symbiosis Method Application}

The Chinese culture theme is shown on the exterior side, while the Betawi culture theme is shown on the material uses. The building uses bright colors such as red, green, and brown, following the colors that are common in both cultures.

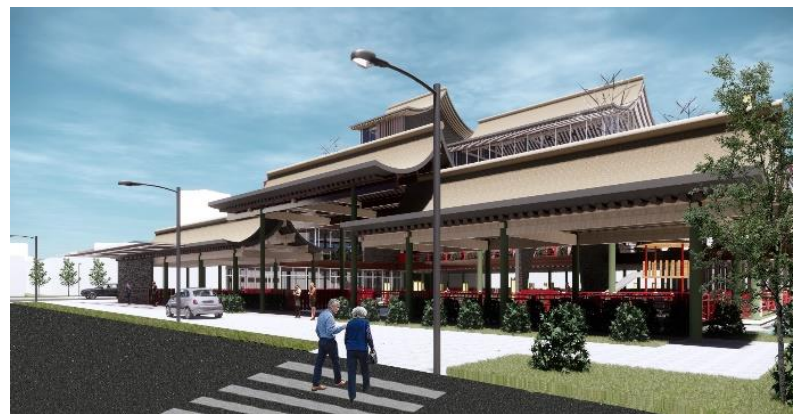

Figure 4. Exterior View

Source: Author, 2020

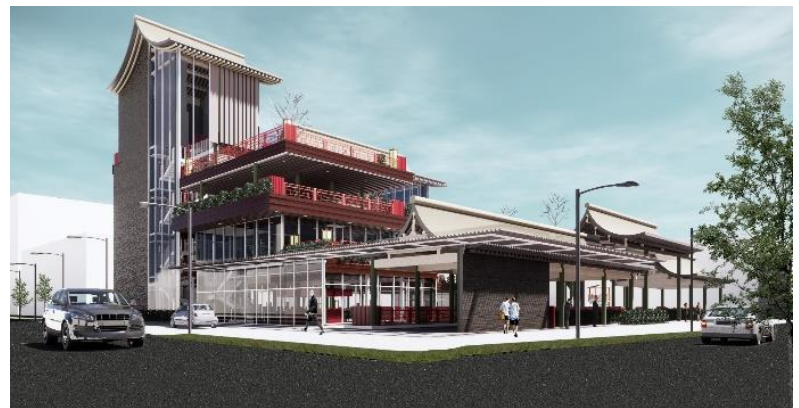

Figure 5. Exterior View

Source: Author, 2020

\subsection{Form Follows Function Method Application}

Building programs are placed following the luo shu concept. Then the mass is designed corresponding to the building program that is placed following the luo shu concept. The building uses round columns to avoid negative energy, according to Fengshui [11].

\subsection{Luo Shu Method Application}

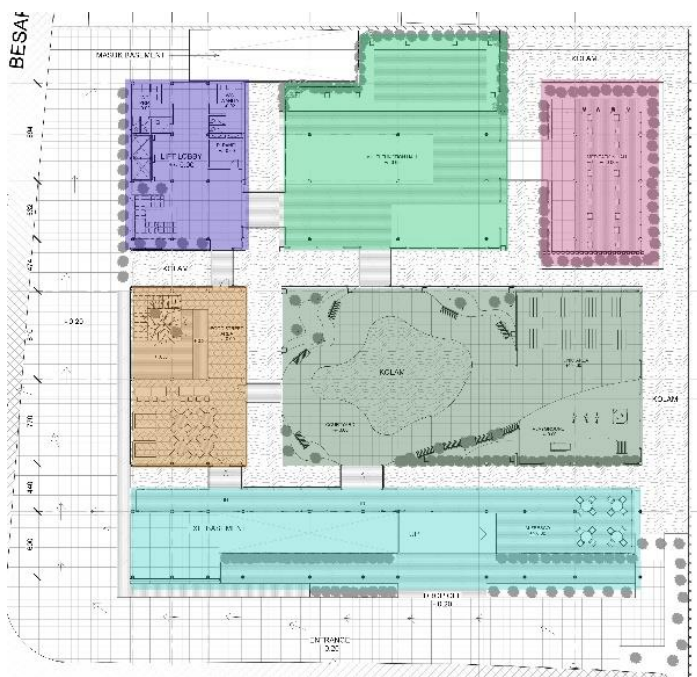

Figure 6. First Floor Plan

Source: Author, 2020

The following shows the relationship between Mangga

Besar Cultural Park and the Luo Shu concept:

1. The blue area resembles the entrance area that is located in the north, specifically in the water phase, to bring calmness and serenity to visitors.

2. The orange color resembles the culinary area which is placed in the east, specifically in the wooden phase.

3. Light green in the south resembles the multifunction hall and gallery area. Located in the fire phase, to uplift the spirit of the visitors, especially at cultural events.

4. The pink color resembles the meditation hall, which is located in the southwest. It is located in the earth phase and far from the entrance and exit to avoid vehicle noises

5. The dark green area resembles the courtyard and playground area. The courtyard area is located in the earth phase, while the playground area is located in the metal area. The courtyard is the center of activity, while the playground is located in a more private place.

6. The purple area resembles the service area, which is located in the wooden phase. It is located near the road to make visitors easily escape in emergencies. 


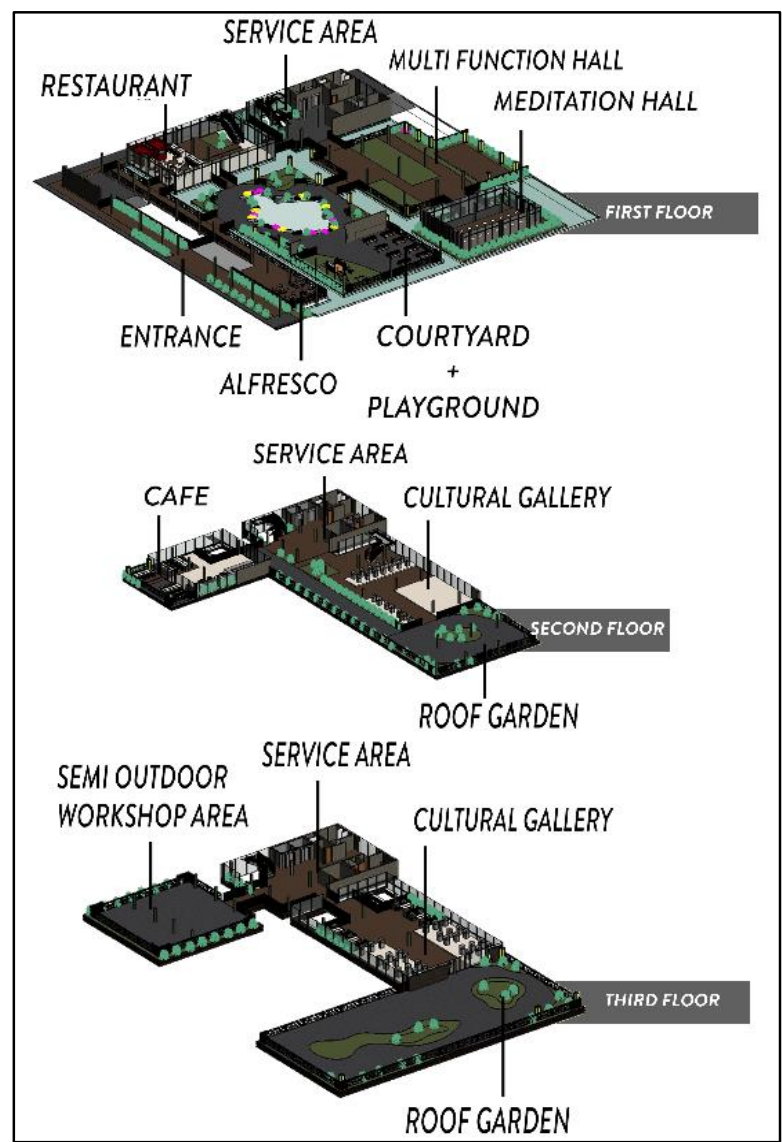

Figure 7. Exploded Axonometric Floor Plan Source: Author, 2020

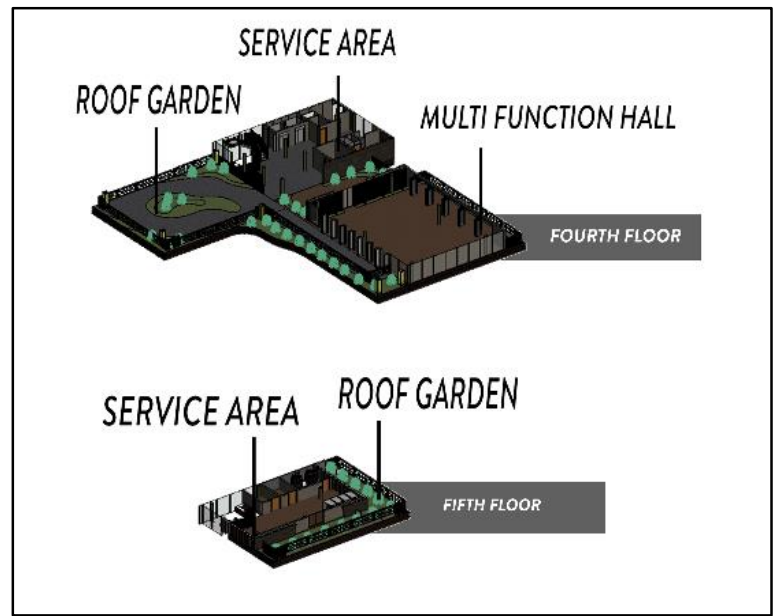

Figure 8. Exploded Axonometric Floor Plan Source: Author, 2020

\subsection{Final Project Result}

Building mass has a cubic form, to adjust its form with other buildings on the site. The façade concept adopts the Chinese culture concept, especially the form of the roof. The colors in the building facade use colors that are commonly found in Betawi and Chinese traditional houses such as red, brown, and green. The exterior uses natural materials, such as stone finishes, woods for second skins and floors, and decorative lights on the edges of buildings. To add a calming and a natural siheyuan impression, pools are added between separate masses, which are not commonly found in buildings around the site. The building also has many natural aspects to balance its harmony with nature, in order to provide benefits, according to fengshui [12]. The interior mainly uses woods such as bamboos and teaks. For example, in the fourth floor's multifunction hall and cultural galleries. The indoor parts of the building mainly use wooden flooring, while semi-outdoor areas such as the workshop room use natural stone flooring. The roof of the building uses a combination of teak and bamboo. Roof gardens on the second and third floor can be used as outdoor exhibition areas since it is directly related to the cultural gallery. The roof garden on the fourth floor can be rented for cultural or private events.

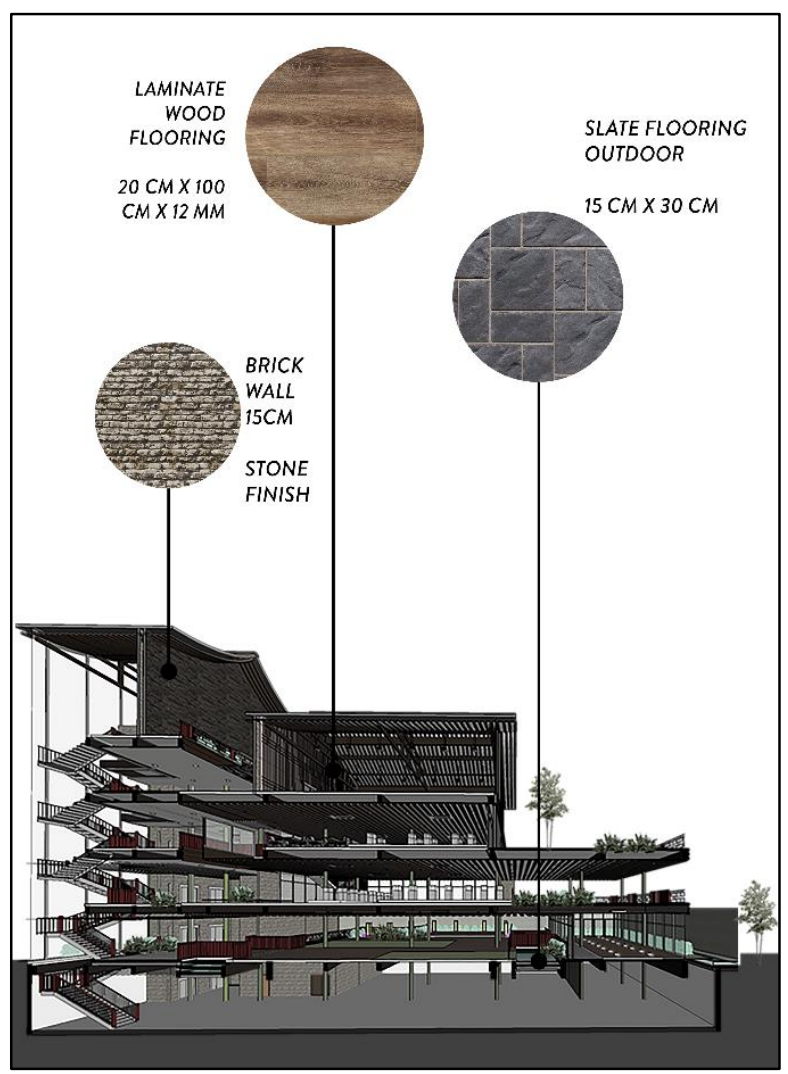

Figure 9. Building Materials Source: Author, 2020

\section{CONCLUSION}

To help overcome the problem of intolerance in Jakarta, the final result of the design is an educational park that belongs to the third-place category, which has a combination of Betawi culture and Chinese cultural themes. Mangga Besar Cultural Park provides cultural education programs in many forms, such as cultural events, exhibitions, galleries, and workshops. This education method could informally deliver 
education in a more relaxing manner. As for the third-place criteria, Mangga Besar Cultural Park is open to the public. The methods used in the design include: Understanding of the design site, determining building programs, symbiosis method application, form follows function method application and the luo shu method application. Two different concepts that will be combined here are the concepts of Betawi culture and Chinese culture. The mass is designed corresponding to the building program that is placed following the luo shu concept. The Chinese culture theme is shown on the exterior side, while the Betawi culture theme is shown on the material uses. The building uses bright colors such as red, green, and brown, following the colors that are common in both cultures.

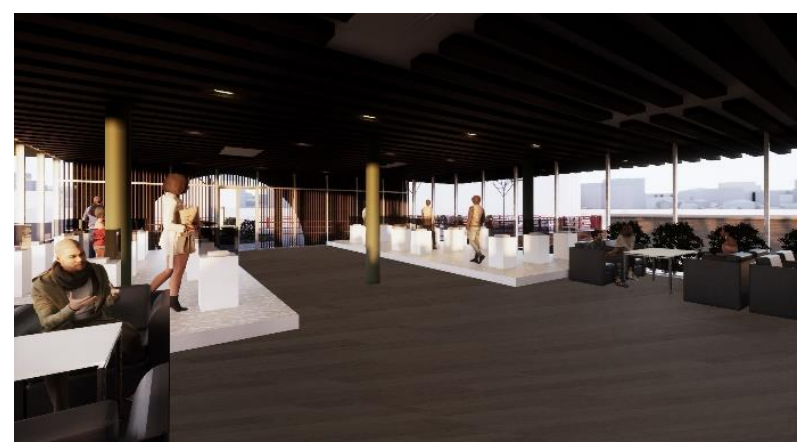

Figure 10. Gallery View

Source: Author, 2020

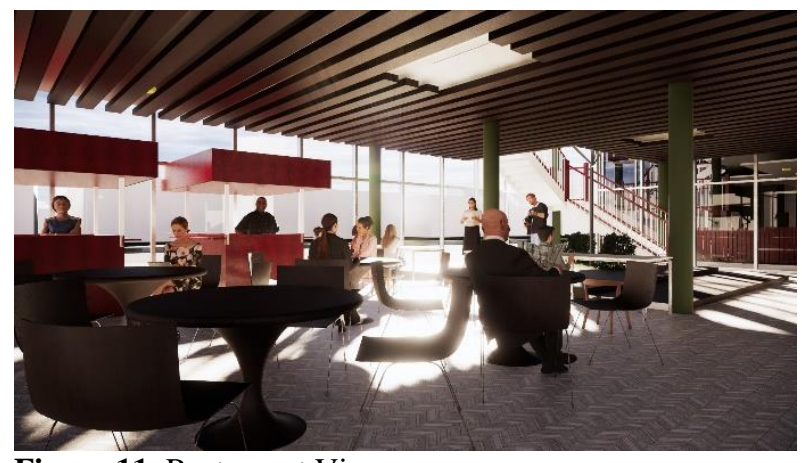

Figure 11. Restaurant View

Source: Author, 2020

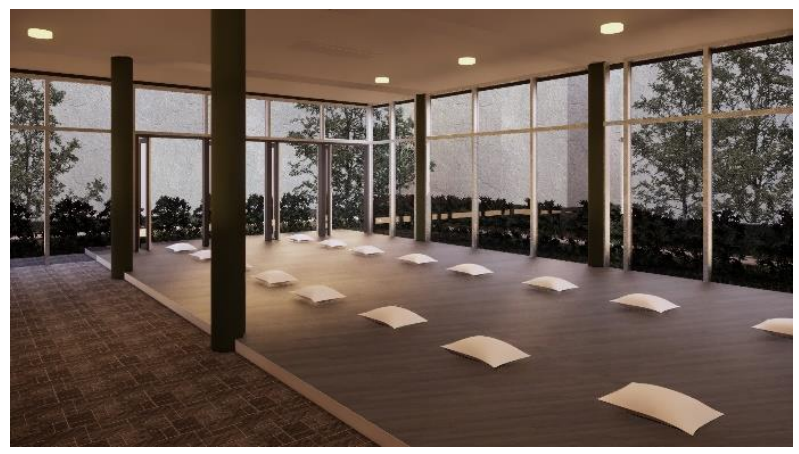

Figure 12. Meditation Hall View

Source: Author, 2020

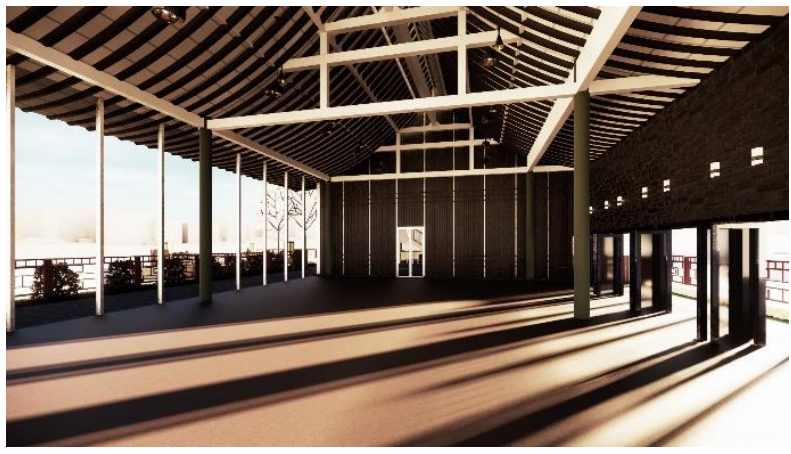

Figure 13. Multifunction Hall View

Source: Author, 2020

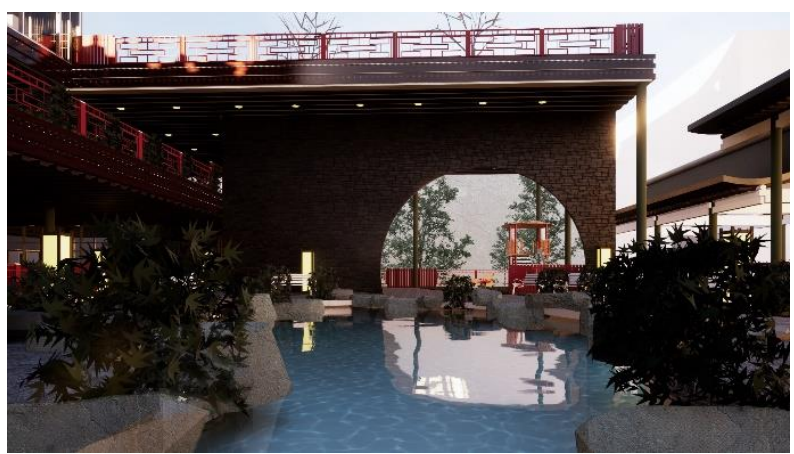

Figure 14. Roof Garden and Courtyard View

Source: Author, 2020

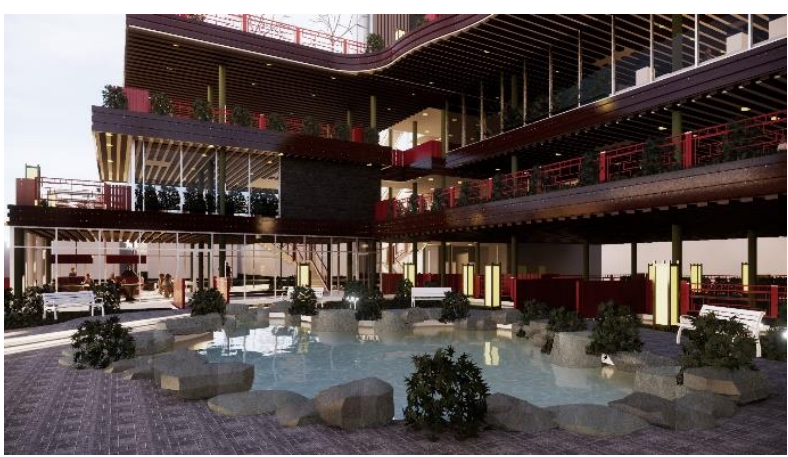

Figure 15. Roof Garden and Courtyard View

Source: Author, 2020

\section{ACKNOWLEDGMENT}

Thank you to LPPM-UNTAR (Lembaga Penelitian dan Pengabdian Kepada Masyarakat Universitas Tarumanagara) for funding this research.

\section{REFERENCES}

[1] D. E. Nugraheny, "Ini Tiga Sebab Menguatnya Sikap Intoleransi di Indonesia Versi Polri," [Online]. 
[2] M. Farid, "Memahani Intoleransi dalam Ruang Publik," 27 Desember 2018. [Online]. Available: https://geotimes.co.id/opini/memahami-intoleransidalam-ruang-publik/

[3] A. Romadoni, "3 Langkah Pemerintah Menangkal Intoleransi di Indonesia," 17 Januari 2017. [Online]. Available: ttps://www.liputan6.com/news/read/ 2828912/3-langkah-pemerintah-menangkal-intoleransidi-indonesia

[4] R. Oldenburgh, "The Great Good Place," in The Great Good Place, Massachusetts, Da Capo Press, 1997.

[5] R. Trisno and F. Lianto, Realization of Hybrid Concept and Symbiosis in Green Open Space (RTH) at Housing Complex RW (Neighborhood Councils) Pluit, Jakarta Utara, Indonesia., 2019.

[6] R. Trisno and F. Lianto, Relationship Between Function-Form in The Expression of Architectural Creation, 2019.

[7] A. Sudikno , P. Salura and S. Kustedja, Kosmologi Media Interpretasi Makna pada Arsitektur Tionghoa Tradisional, pp. 202-203, 2012.

[8] F. Swetz, Legacy of the Luoshu: the 4000 year search for the meaning of the magic square of order three, Massachusetts: A K Peters, Ltd, 2008.

[9] S. W. Teh, F. Lianto and R. Trisno, "Relation between Transit Oriented Development (TOD) and the effect of electromagnetic field with fengshui on residential planning.," IOP Conference Series: Materials Science and Engineering, pp. 1-6, 2018.

[10] DKI, "Peta Zonasi Kawasan Mangga Besar," 2019. [Online].

[11] S. W. Teh, F. Lianto and R. Trisno, "THE IMPACT OF COLUMN AND BEAM CONSTRUCTION SYSTEM TO INTERIOR DESIGN LAYOUT ACCORDING TO FENGSHUI," International Journal of Civil Engineering and Technology (IJCIET), vol. 09, no. 13, pp. 1822-1828, 2018.

[12] F. Studio, "What Is Luo Shu?," April 2017. [Online]. Available: https://medium.com/@floustudio/ what-is-luo-shu-\%E8\%90\%BD\%E6\%9B\%B8-81971 ec0c331.

[13] S. Wiguna Teh, Feng Shui \& Architecture (Feng Shui \& Arsitektur), Jakarta: Gramedia, 2007. 